\title{
Interleukin-6 receptor in the recent-onset rheumatoid arthritis
}

\author{
Marco Antonio Montes-Cano, Sonsoles Reneses, Jose Raul García-Lozano, Fuensanta Torrecillas, \\ Cristina Abad-Molina, Alicia García, Antonio Núñez Roldán, Maria Francisca González-Escribano* \\ From 6th European Workshop on Immune-Mediated Inflammatory Diseases \\ Nice, France. 23-25 November 2011
}

\section{Introduction}

The $\alpha$ subunit of the soluble receptor interleukin-6 (sIL$6 \mathrm{R}$ ) is mainly generated by shedding of the membranebound form. This process is influenced by a functional polymorphism (rs $2228145 \mathrm{~A}>\mathrm{C}$ ) resulting in a substitution of aspartic acid to alanine (D358A) at the proteolytic cleavage site.

\section{Objective}

To investigate the influence of the rs2228145 polymorphism in sIL-6R plasma levels.

\section{Patients and methods}

A total of 141 RA patients and 206 unrelated healthy individuals matched by age and gender were included in the study. RA patients were diagnosed according ACR criteria and they had less than 1 year of evolution at the study time. The sIL-6R protein levels were determined by an ELISA quantitative sandwich and the rs2228145 genotyping was performed using a Taqman assay. Non parametric tests (U Mann-Whitney and Kruskal-Wallis) were used for median comparison and the chi-square test for comparison of the genotypic distribution.

\section{Results}

The sIL-6R median concentration was lower in patients than in healthy control group $(164.4 \mathrm{ng} / \mathrm{mL}$ vs. $185.3 \mathrm{ng} /$ $\mathrm{mL}, \mathrm{p}=0.0002$ ). Moreover, median of sIL-6R concentration was different according with the rs2228145 genotype in both groups, RA patients (AA: 135.8, AC: 189.3 and CC: 233.0, p <0.0001) and controls (AA: 142, AC: 200.2 and CC: $242.7, \mathrm{p}<0.0001)$. When the patients and controls were stratified according to their genotypes (AA and AC

Servicio de Inmunología, Hospital Virgen del Rocío/BIS, Sevilla, Spain
$+\mathrm{CC})$, the sIL-6R median concentration was lower in both patient groups compared with their corresponding healthy controls $(\mathrm{p}=0.01$ for AA and $\mathrm{p}=0.04$ for $\mathrm{AC}+\mathrm{CC})$. Finally, no differences in the distribution of the rs2228145 genotypes were found on comparing patient and control groups $(\mathrm{p}=0.18)$.

\section{Conclusions}

The functional Asp358Ala polymorphism influences the sIL-6R concentration. Nevertheless, additional factors are necessary to explain the lower sIL-6R concentration found in patients since the differences among both groups remain after stratification by genotypes.

Published: 23 November 2011

doi:10.1186/1479-5876-9-S2-P39

Cite this article as: Montes-Cano et al:: Interleukin- 6 receptor in the recent-onset rheumatoid arthritis. Journal of Translational Medicine 20119 (Suppl 2):P39.

Submit your next manuscript to BioMed Central and take full advantage of:

- Convenient online submission

- Thorough peer review

- No space constraints or color figure charges

- Immediate publication on acceptance

- Inclusion in PubMed, CAS, Scopus and Google Scholar

- Research which is freely available for redistribution

Submit your manuscript at www.biomedcentral.com/submit
C Biomed Central

\section{Biomed Central}

